\title{
Making Progress in Content and Language Integrated Learning (CLIL) Lessons: An Indonesian Tertiary Context
}

\author{
Novriani Rabeka Manafe ${ }^{1 *}$ \\ ${ }^{1}$ Program Studi Pendidikan Bahasa Inggris, FKIP, Universitas Nusa Cendana, Kupang, Indonesia \\ Jalan Adisucipto, Penfui, Kupang, NTT
}

\begin{abstract}
This paper outlines an attempt to discover students' progress in both content and language skill in a content and language integrated learning (CLIL) lessons at an Indonesia's higher education context. This is a part of a research conducted at Faculty of Science and Technology of Nusa Cendana University in Kupang, East Nusa Tenggara Province. This study employs mixed method approach with 20 participants attending by taking pre-test and post-test as well as joining a focus group interview particularly for 6 students. The tests were aimed at measuring the participants' comprehension of English as the language of CLIL lesson. They were also used as the tool to evaluate students' mastery of Mathematics as the content subject. Based on the post-test results, the findings showed that more students made significant progress in content subject in comparison to their achievement in language proficiency. Regarding the interview, the students admitted that their failure to made progress in both subjects were mainly caused by their inadequate level of English. This, therefore, led to rising anxiety among the students to complete the tests.
\end{abstract}

\section{Introduction}

This study was undertaken due to the growing interest of Content and Language Integrated Learning (CLIL) implementation in Asia generally and Indonesia in particular. As the teacher at Nusa Cendana University, the researcher began to explore CLIL as a potential design to teach and learn another language and content subject simultaneously. The understanding of an integrated framework design like CLIL approach and the possibility to succeed in Indonesia has inspired the researcher to conduct CLIL pilot project in Nusa Cendana University context. However, since this was an initial step in the implementation of CLIL, the researcher narrowed the focus of the study on the students' progress in CLIL lessons. Therefore, this paper aims at describing students' progress in CLIL lessons, investigating factors which contributed to the progress, discussing problems preventing the

* Corresponding author: novriani.manafe@gmail.com 
students to make progress in CLIL classes and discovering students' expectation from CLIL lessons.

\section{CLIL in higher education}

As suggested by Ramsden (1992) as cited in Fortanet-Gomez (2013, pp. 131-132), there are three approaches to the teaching in higher education level. The approaches are as follows:

1. Telling or transmission process causing students to be passive because they only receive information one-sided from the teacher.

2. Student activity process as student-centered learning which position a teacher as a supervisor.

3. A making learning possible process to support students to construct their own understanding of content subject with assistance from a teacher and peer activities.

Obviously, the third approach is best employed in CLIL pedagogy because it offers scaffolding, synergies and social interaction (Coyle, Hood \& Marsh, 2010). Adding to this, students working alone with scaffoldings from teachers and peers will make progress. If this happens, teacher can reduce the assistance gradually to enhance students' autonomy (Coyle, Hood \& Marsh, 2010).

Furthermore, Rasanen and Klaasen (2004) has pointed out that the major problems in CLIL tertiary classes is the gap between level of language and skills and access to the language used as the vehicular language in the classrooms. Moreover, the language features should be more specific to the subject content. Therefore, the students are expected to have high level of English competence (Dafouz \& Guerrini, 2009, p. 104).

\section{Methodology}

This study employed pragmatic sequential mixed method design to obtain a more sufficient data from both quantitative and qualitative methods (Creswell, 2014). The data quantitative data were the basis for collecting the qualitative data (Mertens, 2010). This research was a part of a larger scale study conducted on piloting CLIL implementation in Kupang, East Nusa Tenggara Province. The research was undertaken in Faculty of Science and Technology, Nusa Cendana University in Kupang, East Nusa Tenggara Province.

\section{Participants}

The researcher received 50 applications to participate in the study. However, there were only 20 students (8 male students and 12 female students) recruited to participate as respondents. The researcher used criterion sampling by which she selected the potential 20 participants based on certain criteria (Bryman, 2012). They signed on the informed consent before participating in the lessons. This was done to ensure their rights to withdraw from the research at any stage. The respondents were taken into account based on the following criteria:

1 They were above 18 years old

2 They were enrolled in the Faculty of Science and Technology, Nusa Cendana University

3 The had passed two subjects incorporated in the lessons namely English and Mathematics.

\section{Data collection}


The study involved the students in 4 lessons where they were taught Mathematics and English at the same time. The data were collected by triangulation of quantitative and qualitative data collection tools. The primary quantitative data of the study were taken by means of criterion-referenced tests to monitor the students' progress (Salvia, Ysseldyke \& Bolt, 2007 as cited in Mertens, 2010, p.356). These tests are divided into pre-test and posttest. Both test consisted of 20 multiple choice questions of English and 10 open-ended Biology questions. Furthermore, the secondary qualitative data were obtained by distributing questionnaires to the 20 students. Preceding the lessons, pre-test was conducted to find out the students proficiency in English as well as the mastery of Mathematics as the content subject. At the end of the lessons, post-test was administered to measure the progress of both the language proficiency and content comprehension. The semi-open ended questionnaires were sent out and returned in sealed and self-addressed envelopes to ensure the anonymity of the respondents from public concern (Mertens, 2010). The questionnaires consist of questions related to problems in making progress in CLIL classes, the contributing factors to the achievement and students' expectation from dual-focused lessons.

\section{Data analysis}

The combination of data collection procedure was followed by triangulation of data analysis techniques. The researcher employed descriptive statistics to present the quantitative primary data from both the pre-test and post test results. The descriptive analysis is suitable for describing and presenting data to find the average score of the students' progress without making any inferences or prediction (Cohen, Manion \& Morrison, 2011). The statistics were presented in tables and charts to describe not only the initial state of the students' proficiency and mastery but also the progress they made after the lessons. The results of the tests the led to the discussion on the factors contributing to the progress and the problems they encountered. This secondary qualitative data were analyzed by using thematic analysis where data from the questionnaires were transcribed and coded as this process generates new ideas and gathers materials by topics (Creswell, 2013; Richards, 2009).

\section{Results and analysis}

\section{Students' progress in language and content}

Based on data collection and analysis, the findings showed that in general all students did make progress after the four lessons. This raw data is presented in Table 1. However, it appears from the table that the respondents achieved higher scores in content subject than in language proficiency. Adding to this, Chart 1 indicates that there was similar trend occurred in both language and content test scores. This can be illustrated by the fact that the number of students scoring below 50 decreased significantly in both English and Mathematics tests. In terms of English, students scoring below 50 declined from 13 students $(65 \%)$ to 4 students $(20 \%)$. Similarly, regarding Mathematics, the number of students fell from 10 students $(50 \%)$ to zero. 


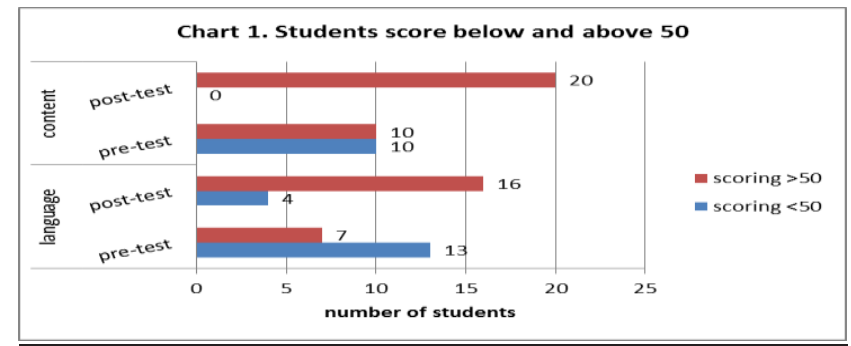

In contrast to the downfall trend in students scoring below 50, there was completely different trend in the number of students scoring above 50 . The rising trend was shown by the amount of students in English increased more than double from 7 students (35\%) to 16 students $(80 \%)$. This is followed by similar notion in Mathematics where the number doubled from 10 students $(50 \%)$ to 20 students $(100 \%)$.

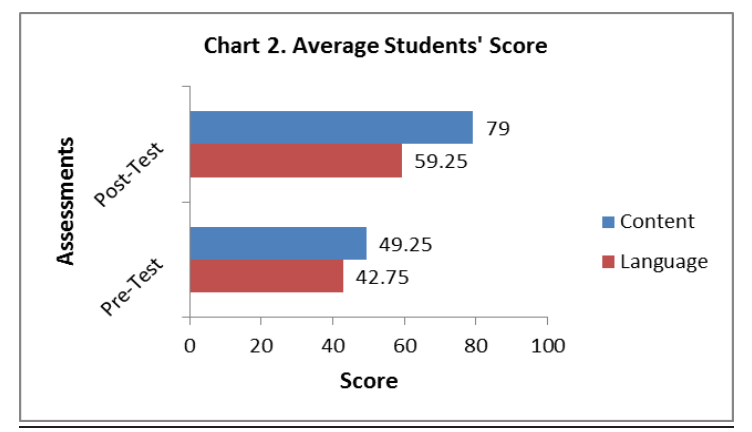

Turning into the average value, Chart 2 clearly points out that there was a growing trend in the average score in language and content subjects. The English average score increased by $16.5 \%$ from 42.2 to 59.25 . Likewise, the content average score inclined by 29.75 points from 49.25 to 79 .

\section{Factors contributing to students' progress}

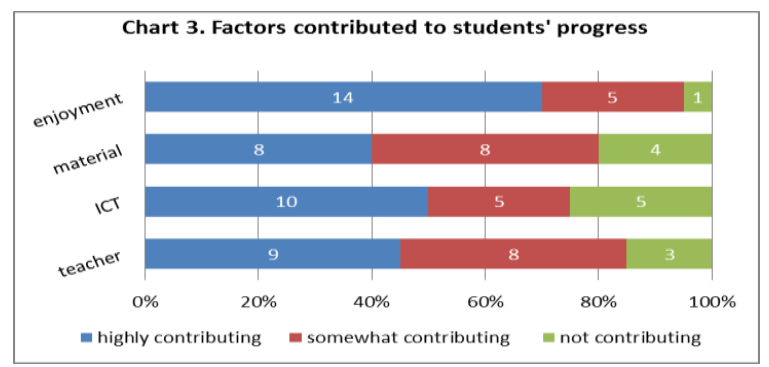

According to the statistics provided in Chart 3, the students revealed the factors contributing to the progress they made in post-tests. The supporting factors relate to enjoyment, teacher's performance, and the use of ICT. In terms of enjoyment, 14 students $(70 \%)$ claimed that they really enjoyed the new experience. Therefore, they become very much excited to join this newly dual-focused learning experience. Thus, it motivated them to make progress. The second contributing factor is material in which 8 students $(40 \%)$ stated that the materials used in during the lessons were very helpful to make them 
understand about the topic. They added that they enjoyed learning with such colorful and updated study resources. Next, 10 students (50\%) mentioned the use of ICT improved their scores. The also described the idea of using audiovisual equipment as a very interactive method to support the learning process. Lastly, 9 students (45\%) acknowledged the teacher's role in enhancing their progress. These students explained the fact that they liked the teacher's performance in delivering the lessons.

\section{Problems in making progress}

Despite the progress they made in the tests, the respondents also pointed out problems that prevented them from making progress in the assessments. The problems mainly arose from language proficiency and little concern from content understanding. First, the language problems lied in the four skills. Based on statistics in Chart 4, problems in writing contributed the highest percentage (90\%). Students said that they were not accustomed to writing in English. Following this, 17 students (85\%) stated that they had issues in speaking. Again, anxiety in speaking became a major issue. Next, 12 students $(60 \%)$ admitted that listening also a difficult topic for them. The students admitted that they had problems following the audio recording because they were not familiar with the accents of the speakers. Lastly, 8 students $(40 \%)$ reported they had difficulties in reading skill. Regarding reading, vocabulary shortage has become a serious problem for the students.

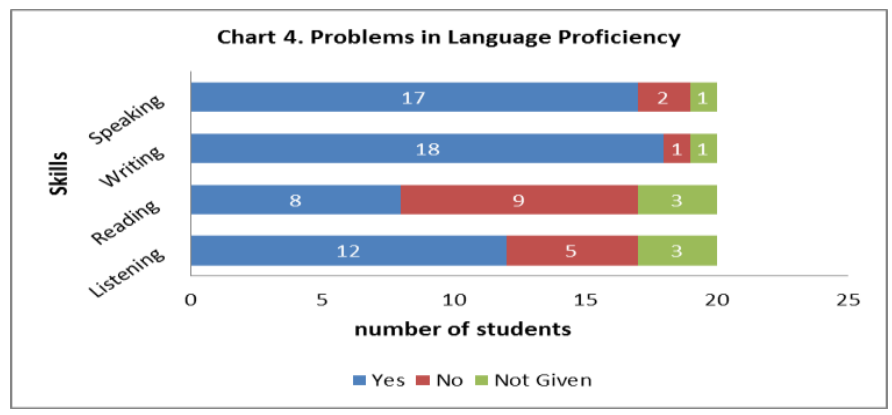

Secondly, regarding content mastery the issues lied in limited vocabulary of the topic being discussed. This can be illustrated by the fact that they had difficulties in understanding content specific vocabularies.

\section{Students' expectation}

Concerning the problems that they countered during the dual focus lessons, the students put forward some suggestions for a better teaching and learning process in CLIL classes. The propositions circled around three notions namely time allowance, teacher performance and English language proficiency. First, the respondents stated that learning a content subject delivered in another language rather than their first language is not only exciting but also challenging. Therefore, they suggest longer time spent in CLIL classes. Second, the teacher who conducted the lessons only used English the whole time which caused the students some difficulties to follow the lessons. Thus, they would be very pleased if the teacher could slow down her voice as well as repeating the difficult words. Third, the major issue in attending CLIL classes was the low level of English proficiency. Then the students 
suggested that those who would like to participate in CLIL lessons need to improve their language skills beforehand.

\section{Conclusion}

This mixed method study which combined qualitative and quantitative data collection and analysis from 20 participants have brought some evidences into the implementation of tertiary CLIL projects in Kupang context. The findings from the research answered four objectives namely investigating students' progress in both language and content comprehension, addressing the contributing factors to the achievement, delineating the problems preventing them to make progress and discovering students' expectancies from CLIL lessons.

Concerning students' achievements, it was obvious that the learners made progress in both subjects. However, the progress that they made in content knowledge was significantly higher than their language skills. Despite the difference in level of achievement between content and language, there were some factors that contributed to their progress. The supporting variables were enjoyment, learning resources, use of ICT and teacher's delivery method.

Turning into the factors that prevented the students from achieving higher scores in language skills, the main issue was that the proficiency of the students was below average. Therefore, they had difficulties in all the four skills as well as in content comprehension. In accordance to the contributing factors and the problems stated above, the students exposed positive value towards the research. They brought out some suggestions to improve the quality of CLIL dual-focused lessons. First, they stated that these typical lessons should be conducted in longer time span because they need more opportunity to learn two subjects in one lesson. Next, the students definitely agreed with the idea of improving their English skill to be able to participate in CLIL lessons. Finally, the students proposed repetitions and slow speed from the teacher so they could adhere well to teacher's presentation.

\section{Acknowledgement}

This research was a pilot project conducted at Fakultas Sains dan Teknik of Universitas Nusa Cendana in Kupang, East Nusa Tenggara Province. Therefore, I would like to show my gratitude to colleagues at the faculty who provided assistance for the completion of this research. I also thank students at the faculty who participated as respondents in this research.

\section{References}

Bryman, A. (2012). Social Research Methods. Oxford: Oxford University Press.

Cohen, L., Manion, L. \& Morrison, K. (2011). Research Methods in Education. Oxon: Routledge.

Coyle, D., Hood, P., \& Marsh, D. (2010). CLIL: Content and Language Integrated Learning. Cambridge: Cambridge University Press.

Creswell, J. W. (2013). Qualitative Inquiry \& Research Design: Choosing Among Five Approaches. California: Sage. 
Creswell, J. W. (2013). Research Design: qualitative, quantitative and mixed method approaches $\left(4^{\text {th }}\right.$ ed). California: Sage.

Dafouz, E. \& Guerrini, M.C. (Eds.), 2009. CLIL Across Educational Levels. Madrid: Richmond Publishing.

Fortanet-Gomez, I. (2013). CLIL in Higher Education: Towards a Multilingual Language Policy. Bristol, Buffalo and Toronto: Multilingual Matters.

Gibbons, P. (2002). Scaffolding Language, Scaffolding learning: Teaching Second Language Learners in the Mainstream Classroom. Portsmouth: Heinemann.

Hunt, M. (2011). Learners' perceptions of their experiences of learning through a foreign language. Educational Review, 63(3), 365-378.

Mehisto, P., Marsh. D. \& Frigols, M. J. (2008). Uncovering CLIL: Content and Language Integrated Learning in Bilingual and multilingual Education. Oxford: Macmillan.

Mertens, D. M. (2010). Research and Evaluation in Education and Psychology: Integrating Diversity with Quantitative, Qualitative and Mixed Methods. California: Sage.

Richards, L. (2009). Handling Qualitative Data: A Practical Guide. London: Sage 